\title{
GOLD, TADPOLES AND JESUS IN THE MANGER: MYTHOPOEIA, COLONIALISM AND REDRESS IN THE MOROBE GOLDFIELDS IN PAPUA NEW GUINEA
}

\section{DANIELE MORETTI}

In 1936 Beatrice Blackwood became the first ethnographer to work with the Anga people of Papua New Guinea (PNG). ${ }^{1}$ In her own words, her aim was to learn "what [she] could of the life of a modern Stone Age people..., for in this way an ethnologist can sometimes fill up some of the gaps in the archaeological record" (Blackwood 1939: 11). Of course, this attempt at anthropological time travel (Fabian 1983) was only made possible by the "pacification" of a small number of Upper Watut villages following the discovery of gold in the neighbouring Wau-Bulolo Valley and Mount Kaindi over the previous decade. For the Anga of the Bulolo District, the opening of the Morobe Goldfields in the 1920s marked the beginning of a new colonial epoch. Beyond that, the event encouraged prospectors and administration to push inland in search of similar strikes, thus promoting the spread of colonial power, not just to the core of Anga country but also to the wider Highlands region.

Between the 1920s and PNG national independence in 1975 the Morobe Goldfields produced great mineral riches that transformed the townships of Wau and Bulolo into booming industrial enclaves and sustained colonial expansion throughout the Mandated Territory of New Guinea (a political unit subsequently united with Papua under colonial rule). Yet little of this wealth was spent for the benefit of the Upper Watut or of the Anga more generally. What is more, just as independence approached and growing numbers of Anga became involved in the Goldfields' economy, the Bulolo District's large-scale mining industry ground to a halt and local employment opportunities and services declined significantly. This led to a spiralling process of socio-economic stagnation that gathered pace rather than reversed in the postcolonial era.

Between 2001 and 2007 I carried out three spells of ethnographic research in the Kaindi area of the Bulolo District. Located to the south of the Wau Valley, between the headwaters of the Upper Watut and Bulolo Rivers, Mount Kaindi peaks at 2,500 metres above sea level. At the time of fieldwork the area was occupied by a community of over 2000 indigenous miners, most of whom were first, second and third generation Hamtai (with a few Menya) speaking Anga migrants from the Upper Watut, the Menyamya District of Morobe and the Kaintiba Sub-District of Gulf Province. 


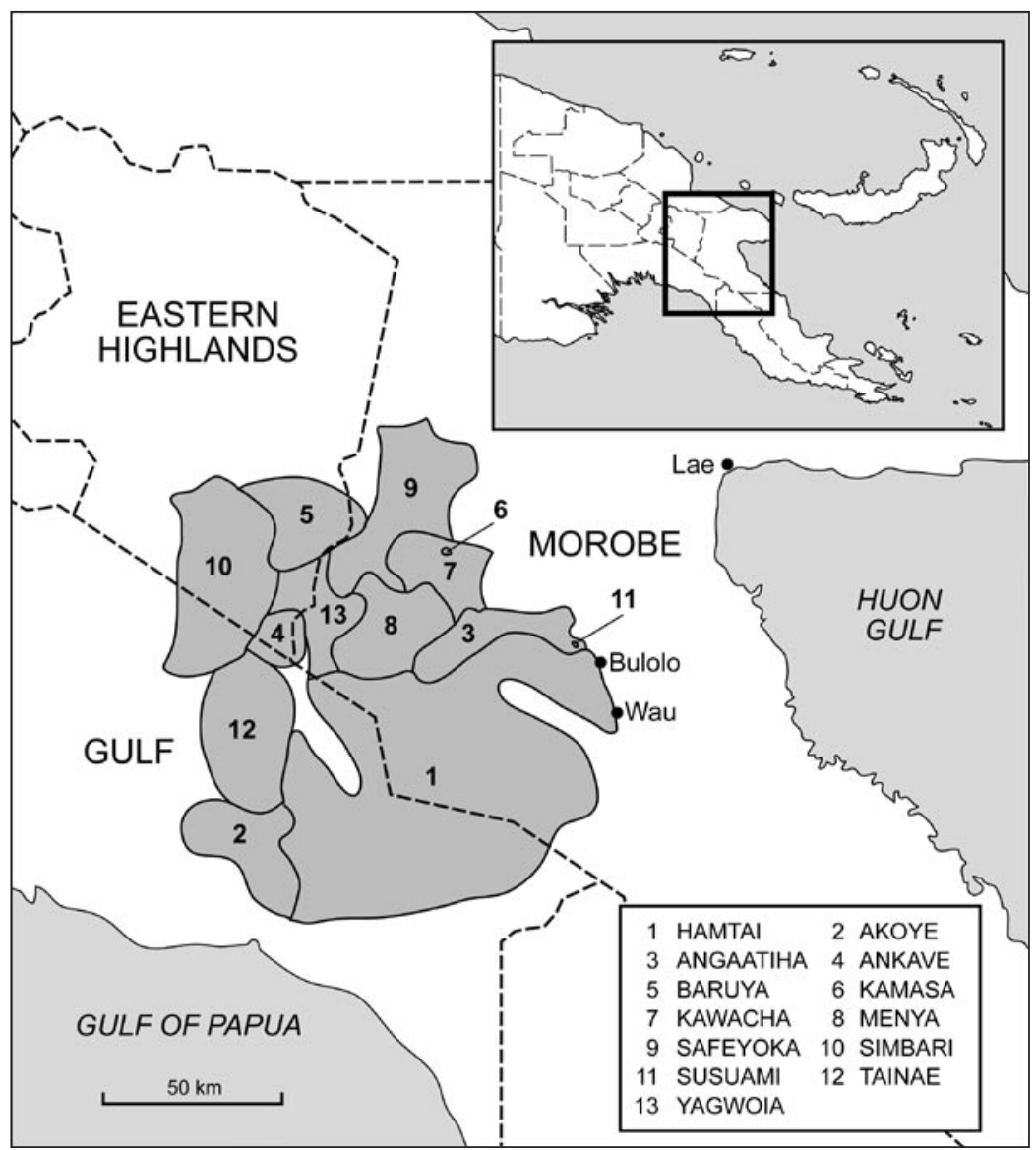

Map of the Anga ethno-linguistic region with boundaries of its 13 language groups.

Within days of first reaching the field I learned that a long history of colonial dispossession and missed opportunity, of which I offer an overview in the first part of the article, has left local Anga communities with a deep-rooted feeling of having been excluded from the benefits that accrued from the development of their resources. Rather than being simply articulated by reference to the immediate colonial past, however, Anga demands for compensation and restitution are framed in terms of a complex web of mythical accounts that 


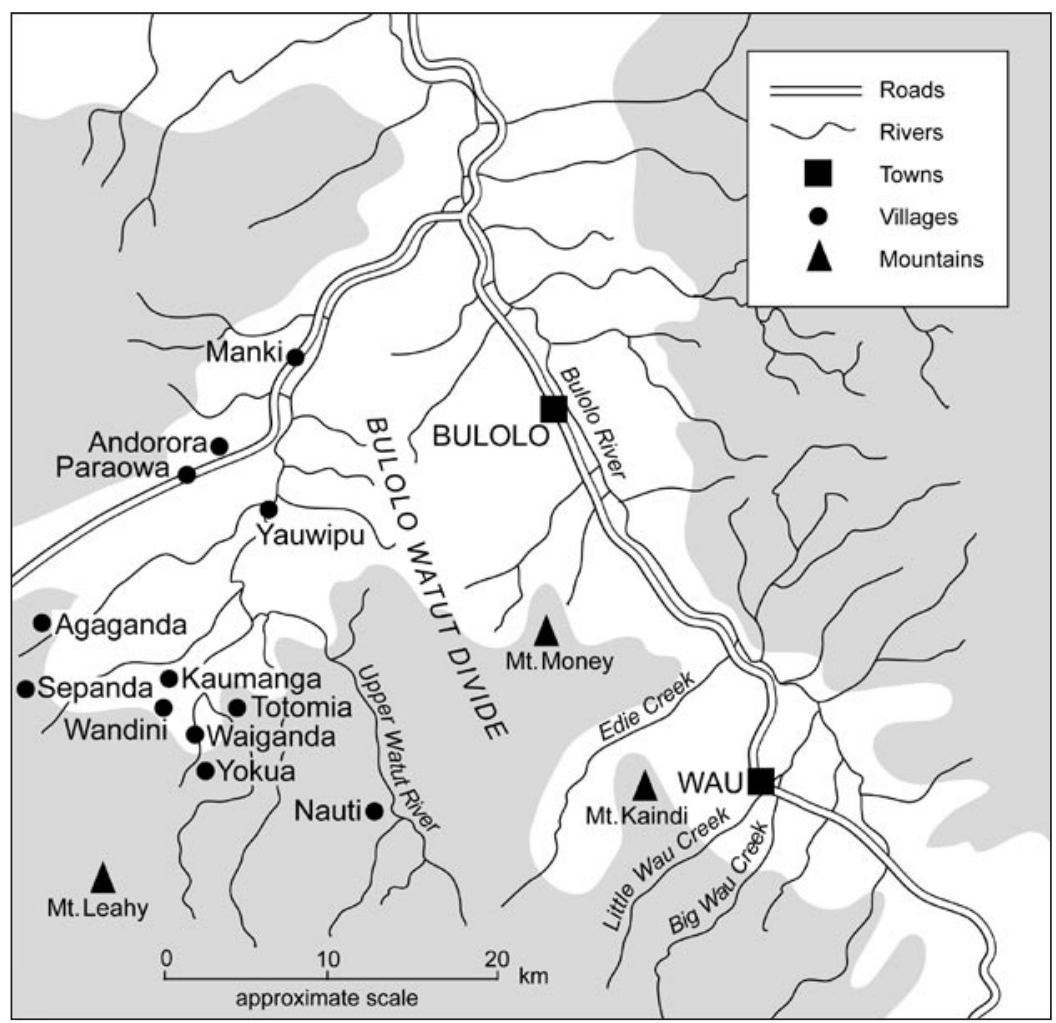

Map of Mount Kaindi and the Wau and Bulolo area.

trace the unfolding of Anga/non-Anga relations across the totality of cosmic time, from the primordial scene of creation to the future.

The second part of this essay considers several examples of these contemporary myths that I collected from Hamtai-Anga informants from both the Upper Watut area and the aforementioned migrant communities of Mt Kaindi, which I contrast with similar material obtained by Blackwood (1978) in the 1930s. The aim will be to illustrate the complex range of local opinion about the colonial past and consider the different strategies Anga actors envision for the future redress of its injustices. In so doing, the essay adds to a long list of works showing that myth constitutes what Kirsch (2006) called a form of "indigenous historical analysis" whereby local actors seek 
both to give meaning to and reshape their past, present and future exchanges with one another, other indigenous groups and peoples outside PNG. As such, myth is a crucial sphere of indigenous creativity and agency that can reveal the complex ways in which history and culture, and local and global forms and practices, continually interact with and transform each other, thus enabling anthropologists and historians to investigate the effects of past and present power inequalities in a manner that transcends reductionist models of indigenous agency as mere "reaction" or "resistance" (see Biersack 1991, Jorgensen 2001, Thomas 1997). In addition, the essay will argue that the symbolic "polysemicity" and "multivocality" (Turner 1967) of myth allows it to speak at once the language of unity and that of conflict and difference, making it an invaluable arena for grasping the full complexity of the identity politics and power struggles that shape indigenous understandings of the colonial encounter and of the trajectory of future relations between colonisers and colonised. Finally, this essay proposes that myth offers a unique means of contextualising and elucidating the wider moral dimension of the aspirations towards renewal, recognition and equality that are embodied in what may easily be misunderstood as simple, targeted requests for the restitution of specific and objectifiable quantities of misappropriated land and wealth (Burridge 1995, P. Lawrence 1989, Lindstrom 1993, Worsley 1968).

THE MOROBE GOLDFIELDS, 1922-2007

The first proven gold discovery in the Morobe Goldfields took place at Koranga in 1922 (Healy 1965: 115, 1972: 500). In 1926 a richer find was made at Mount Kaindi. This sparked a gold rush that, in decades to come, attracted unprecedented numbers of miners, entrepreneurs and adventurers from every corner of the globe, as well as thousands of indentured labourers ${ }^{2}$ from all over New Guinea (Imbun 2006, Sinclair 1998: 103, 106). While some independent miners did strike it rich, many were never so lucky. Soon the easily workable gold began to wane and most small operators were forced to sell their claims to bigger interests and prospect out of Morobe (Healy 1972: 500). From then on, small-scale mining became secondary to the operations of larger companies like Bulolo Gold Dredging (BGD) and New Guinea Goldfields (NGG) (Healy 1972: 500, Halvaksz 2008), a transformation that heralded the beginning of large-scale industrial mining in PNG. Thanks to these larger companies the Goldfields were opened to air transportation. Within a decade, Wau and Bulolo grew into booming colonial enclaves and their extractive industry stimulated the growth of Salamaua and Lae, which is today PNG's second largest city (Sinclair 1998).

This remarkable outburst of industrial development came to a halt during the Second World War, but by then the Goldfields had yielded 69,627 kg of 
gold and 43,799 $\mathrm{kg}$ of silver (Lowenstein 1982: 136). According to Nelson (2001: 200), "by 1940 the Territory of New Guinea was exporting over $£ 3$ million worth of gold, nearly all of it from Morobe", and the mining industry had saved New Guinea from the devastation that the Great Depression had caused to the plantation industry. Thanks to the mining royalties, import duties and other public revenues they had generated, the Morobe Goldfields spearheaded a massive increase in administration revenues (O'Faircheallaigh 1989, Sinclair 1985: 92) and, as one commentator put it, were instrumental in "keep[ing] the Territory financially afloat at no cost to the Australian tax payer" (Tudor 1977: 67). ${ }^{3}$

While colonisation on the cheap was undoubtedly good news for the Commonwealth government, O'Faircheallaigh (1989) showed that in prewar New Guinea mining revenues were used overwhelmingly to benefit the Territory's expatriate community rather than its indigenous peoples, and this pattern of exclusion was certainly also true of the Upper Watut and neighbouring Anga groups. According to historical records, when colonialism reached Wau and Bulolo the Upper Watut Anga were at war with each other and with the Biangai people who lived southeast of Wau. ${ }^{4}$ The colonial administration quickly labelled thousands of hectares in the Wau Valley and Mount Kaindi area "Waste and Vacant", declared them "Crown Land" and opened them to colonial settlement and exploitation. Later on, as the Koranga and Kaindi deposits began to wane, hundreds of prospectors moved into the Upper Watut. Those local communities that tried to protect their land were repressed by patrol officers and, in some cases, forced to resettle elsewhere to provide new grounds for European exploitation.

In addition to suffering land alienation, the Upper Watut and their Anga neighbours were largely cut off from the trade, employment and other economic opportunities generated by the local mining economy. By the first decade of the 20th century the "Kukukuku" (as the Anga were then known among BritishAustralian colonisers) had already acquired a universal reputation as the most treacherous, bloodthirsty and capable fighters of Papua New Guinea (Healy 1965: 114, Nelson 2001: 194). The Upper Watut were no exception to this and attacks on expatriate miners and indentured labourers were not uncommon. For their part, the mining community tended to respond repressively to acts of indigenous assertiveness, so that interactions between the two groups remained on the whole sparse and marked by mutual suspicion and even violence (Burton 2001, Leahy 1994, Roberts 1996, Simpson 1953, Sinclair 1966, 1998). As a result, by the mid-1930s there were 240 foreign miners in Morobe and 2,500 New Guinean labourers operating in the Otibanda area of the Upper Watut, yet all the indentured labourers had come from other parts of New Guinea and only a few Anga had accepted employment with the miners. Similarly, 
though by this time some Watut communities had started to grow introduced crops to sell to the expatriate enclave, this trade remained rather limited in both volume and scope (Simpson 1953, Sinclair 1998: 131).

After the Second World War, mining restarted in earnest (Healy 1967, Sinclair 1998). It was only in this second phase of development that significant numbers of Anga entered the Goldfields' economy as indentured labourers, and it was only in the 1950s and 1960s, when mining operations were already winding down and the expatriate community gradually departing, that PNG miners began to work independently of expatriates (Lowenstein 1982: 15, Nelson 2001: 200, cf. Halvaksz 2008: 25). Before then individual expatriate miners, companies and colonial administrations alike were only interested in New Guineans as labourers and remained reluctant to make gold-bearing grounds available for them to work independently. It was only through the efforts of a first nucleus of indigenous miners, a change in administration policy and the help of some sympathetic NGG supervisors and mining wardens that the situation gradually changed and Papua New Guineans began to be issued their own mining permits (Burton 2001, Sinclair 1998: 337-38).

From then on, more and more Papua New Guineans mined gold independently and by the 1970s over 2000 indigenous miners were collectively responsible for some 80 percent of the Morobe Goldfields' annual alluvial gold production and 45 percent of their total yearly output. But despite this rapid increase in indigenous participation in mining only 29 percent of the gold extracted from Morobe to 1977 was won by Papua New Guineans (Lowenstein 1982: 16, 137; Sinclair 1998: 337). As expatriates began to leave in anticipation of independence and larger companies scaled down their operations, hundreds of their Finschaafen, Sepik, Highlands, Kunimaipa and Goilala labourers were left behind. Unwilling or unable to return to their villages, many settled in the goldfields and started their own mining operations, so that a significant portion of the gold produced by nationals in the postwar Morobe Goldfields was actually won by non-Anga peoples.

Apart from an increased presence in the Morobe extractive industry, in the postwar years, rural Anga communities began to benefit from cash cropping initiatives sponsored by the Administration (Sinclair 1998: 350). But while postwar administration policy did make an unprecedented commitment to the "development" of the whole of PNG, in the Upper Watut or wider Angaland crucial services and infrastructure like schools, aid posts, roads and airstrips did not appear until the late 1960s or early 1970s, or just a few years before national independence. While the late arrival and limited nature of local infrastructure and services was also common to other parts of the country, my Anga informants held that their people had been especially marginal to these developments, not just by comparison to the expatriate enclave that 
lived within view in the Morobe Goldfields, but also to other Papua New Guineans living on the coast, in the islands or along the Sepik, who were perceived to have "unfairly" received more economic opportunities and government and mission services and infrastructure from a much earlier time than themselves.

To this day, the people of the Upper Watut remain disadvantaged in terms of their access to capital, health and education compared to other people within the Bulolo District, Morobe Province and wider Papua New Guinea (Jackson 2003). Similarly, the Menyamya District of Morobe and the Kaintiba Sub-District of Gulf Province, from which most of the other Anga settlers in Wau, Bulolo and Kaindi originate, continue to suffer from inadequate or absent infrastructure and services, poor soil fertility and growing population pressure. As a result, their people live on average incomes of just 0-40 kina ${ }^{5}$ per annum, which is quite low even by national standards (Hanson, Allen, Bourke and McCarthy 2001).

Another postwar development in administration policy involved a greater recognition of indigenous rights over alienated land. In the Wau-Bulolo area, this had enduring repercussions on local power relations. In 1962 the Biangai initiated a dispute over 6,000 hectares of "Crown Land" alienated in the 1920s, which included the Wau Township and several historical agricultural and mining leases that had long been occupied by Hamtai miners from the Upper Watut and Aseki regions. Ten years later the Supreme Court found the Biangai and not the Upper Watut to be the customary owners of the area. Rightly or wrongly, this decision made the Anga feel like they had been twice dispossessed - first, by the Australian colonisers, who alienated the "6,000 hectares" for foreign exploitation and then returned it to the "wrong" claimants through the Supreme Court and, second, by the PNG State, whose Land Courts have been responsible since independence for upholding this colonial "miscarriage of justice".

Just as they were beginning to enter and share in its benefits, Anga saw the economy and society of the Morobe Goldfields fall into a spiral of decline. In the postwar era BGD, the largest company in Bulolo, gradually closed its mining operations, bringing them to a complete halt by the mid-1960s (Healy 1972: 501). Similarly, NGG wound down operations in the Wau Valley and Mount Kaindi, and just a year after Independence it shut its Wau sawmill, putting 140 people out of work. By the end of the 1970s most expatriates had left Wau, which had started to suffer from a serious economic slowdown, rising unemployment and fast growing immigration (T. Lawrence 1994, Sinclair 1998). By the early 1990s all NGG operations had closed down. As this company was not only the major local employer, but also the provider of a range of essential medical, educational and subsistence services, its closure 
proved a devastating blow to Wau and its surrounding communities (NGG Holdings Limited 1985, Sinclair 1998). At the same time, and probably at least in part because of this loss of services and employment opportunities, law and order problems began to increase (Sinclair 1998: 393-95, 442). Soon the area acquired a national and international reputation for violence that endures to this day (see also Halvaksz 2006).

When I last left the field, the future of the Wau-Bulolo District rested on a combination of old and new prospects. Artisanal gold mining, forestry and cash cropping continued to make significant contributions to the economy. In terms of newer developments, a medium-scale gold mine owned by Morobe Consolidated Goldfields (MCG) was expected to enter production in 2009 (Halvaksz 2008) and to have a significant economic impact on the District through direct employment, demand for goods and services, the payment of rent and royalties to local landowners, and the provision of new community services and infrastructure such as aid posts, roads, and contributions to schools, churches and other local bodies (Howard 1991, Jackson 2003). From its very outset though, the planning of this development had been punctuated by a series of fierce disputes between local communities over the ownership of its two main prospects. Like the dispute over the " 6,000 hectares", this particular "resource war" is linked to the colonial history of the Morobe Goldfields, whose strong character of dispossession and missed opportunity, combined with desires for social and political recognition if not pre-eminence among local groups, made both Biangai and Anga communities determined to secure as much as they could from future mining development (Burton 2001, Jackson 2003).

\section{THE POLITICS OF MYTHOPOEIA IN HAMTAI-ANGA DISCOURSE OF COLONIALISM AND REDRESS}

In 1936, Blackwood heard several versions of an origin myth from her Watut informants. Despite variations, all renditions shared a common plot that cast the emergence of humanity as a process of progressive differentiation from an initial state of unity (Wagner 1978). This story begins with the death and burning of a first ancestor, whose charred skeleton is placed in a stream or a pool. Through the regenerative and procreative power of water, the ancestral bones are transformed into a multitude of human beings. Thereafter, the new humans are divided into groups by a male or female culture hero and given an ancestral language, name, territory, ornaments and customs. While certain versions of the creation myth view the primordial differentiation of humankind as an "apolitical" process, others present a different picture, where the emergence of humans is linked to evaluative differences among groups.

To understand what I mean by this, one must consider the crucial links between fire, light, power and humanness that pervade Anga discourse and 
practice. To begin with, some of Blackwood's (1978: 163) material suggests that, at the time of creation, people faced total darkness because there was no sun and no moon. Only later did these celestial bodies rise to the sky. As such, fire was the only means the first people had to warm themselves, and to see and know each other and the world around them. Indeed, many versions of the origin myth I heard seven decades later suggested that it was only through the light of campfires and torches that the ancestors were able to migrate from their place of origin to the land the culture hero assigned them.

Beyond its importance in the primordial darkness of creation myths, the capacity of fire to cast light on what is dark and hidden resonates with a diffuse Anga association between power and clarity of vision, which is in turn closely related to all valuable and secret knowledge. Indeed, the most knowledgeable and ritually powerful Hamtai-Anga figures are called hingo' wanga [Hamtai: 'seers'] because of their ability to see what is hidden to ordinary people, and thus to communicate with the spirit world, combat witchcraft and rid the sick of disease.

In addition, Anga culture assigns pervasive creative force to fire and heat. Like the myth presented above, tales collected by Blackwood (1978), Bamford (2007) and myself relate how the first ancestors, plants or other elements of the cosmos emerged from human bodies which had been burnt down and thus made fertile by the procreative power of flames. Similarly, many Anga groups consider heat to be directly associated with the human reproductive organs and substance and to be necessary to conception (Godelier 1986: 6467, Herdt 1981: 249-50, Mimica 1981: 119-21).

If fire and heat are associated with sex and procreation, they are also directly connected with secret knowledge and ritual. Indeed, when my informants revealed extremely powerful and secret ancestral names, histories and myths they would often sweat, sigh and take frequent pauses to blow on their chests, hands and arms to "cool themselves down". At times, they would even stop narrating for a while, claiming that the power of their words had made their bodies "as hot as fire" and was endangering their health. Similarly, many other Anga groups held that sacred rituals like male initiations made the bodies of participants hot to the point of being dangerous to non-participants and even themselves unless adequate precautions were taken (for example, Bonnemère 1996: 311-33).

Because of the power of fire to illuminate, fertilise and transform raw materials into cooked and consumable food, the capacity to create and control it is for the Anga one of the foremost symbols of humanness. To give just an example of the close association between possessing fire and being human, one of the origin myths I heard in the field explained that before the ancestors of today's human beings were created, there existed another race of people 
who lived with the primordial culture hero. These people did not know how to make fire and cook, so they only ate raw meat and their stomachs were full of blood (parasites) and swollen. Unlike them, the culture hero knew the use of fire and was so disgusted by the "unclean ways" of this prehuman race that he killed every one of them with a rain of fire and, from their burnt bodies, created the first ancestors of present-day humans.

Given the above, it is easy to appreciate the importance of another version of the myth collected by Blackwood. In this rendition, after the first ancestors emerged from the tree, the culture hero discovered that only the Kukukuku could speak his own language properly. Displeased with the "bad talk" of the other people, he:

Sent them away, [so that] they sat down on the outside. The ones who had good talk [i.e., the Anga in general and the Upper Watut in particular] sat down in the middle. Those who sat down on the outside eat possum raw. They sit in dark places and have no fire. (Blackwood 1978: 157)

According to this account of the origin myth, of all the peoples of the world the Kukukuku alone emerged from the creation pool as fully human beings capable of true speech. For this reason, they alone were blessed with the powerful knowledge of fire while all others remained, literally and figuratively, "in the dark", eating raw food like the animals of the wild.

To conclude this brief review of Upper Watut origin stories from the early colonial era, I would like to mention a last mythical trope of differentiation and separation, whose significance shall become clear later on in the paper. In some of Blackwood's (1978: 158) material, the migration of the differentiated groups from the place of creation to their respective ancestral lands is followed by an incident where a river of salty water springs forth from the earth, a pool or a mountain and carries a group of unidentified Anga ancestors to the ocean.

Within days of my first arrival in the Bulolo District I heard a modern version of the Hamtai origin myth. While following a similar structure to those collected by Blackwood, this rendition differed from earlier ones in that it told how "whites" had also emerged from the same pool/tree as the Anga, and how immediately after creation they had travelled away to the coast taking all the "cargo" with them. Thus, like the modern Lake MurrayMiddle Fly wandering hero tales analysed by Busse (2005), in the colonial and postcolonial era the Hamtai origin myth that had always expressed ideas about similarities, differences and relations between local groups of people also came to comment on those between Melanesians and whites. As months went by and I heard version after version of the myth, I realised that my informants employed it not only as a point of departure for their reflections on what they 
regarded as the most salient occurrences of colonial times, from the arrival of whites to their departure and the "plunder" that took place in between, but also as a means of articulating visions of how past wrongs should be redressed and positive relations between themselves and the former colonial masters (re)established in the future.

To explore these myth-based discourses on colonialism and redress I will draw on an encounter that took place just before I left the field in 2005. As I was travelling back from the mines one evening I encountered an old Hamtai man from the Upper Watut. Jacop ${ }^{7}$ had lived and worked in Kaindi for decades and I had already interviewed him on a few occasions over the previous year. That particular day Jacop stopped me for a chat and, when I mentioned that I was about to return home he asked me to visit him the next day for a final "story". The following morning Jacop proceeded to share the reasons for my summoning: ${ }^{8}$

This is what has been worrying me: How did God create Heaven and Earth? Whom did He create first? You whites or us Kukukuku? We have our own history. It goes like this... in the beginning God created a woman and a man and put them on the ground and gave them many gifts. At that time there was another man too, and every time the married man and woman had children this other man would steal and eat them.

He ate the couple's first child, the second, then he took away the third. But this time the other two got very angry and followed him home. When they got there, they spied inside and saw that he was eating their child, so they blocked the door of his house and set fire to it. As the house burnt, they listened to the man's screams until they heard the big pop of his head bursting and they knew he was dead. When the fire died out, they searched the ashes and rubble, gathered all his bones, put them in a nearby e'a pnga [Hamtai: 'pond or bog'] and left.

After some time they went back to the water and saw that the man's bones had turned into tadpoles [Hamtai: ämamango], then they left again. After one moon they returned. This time they found that the tadpoles had sprung human heads. They went away for another moon, and when they returned and looked in the water they saw all the tadpoles had turned into little men, and that their skins had different colours. Some of them were white, some black. There were many of them, so many that they filled the whole pond. When they saw all these people, the man and woman went away and made traditional dresses for them, because they were all naked.

When the tadpoles became true men the couple gave clothes to the Kukukuku, who had already come out of the water. But some other men, the white men, were still naked in the water. When the couple saw this they asked themselves: 
"what kind of men are these who are still naked? God made them, so He must know who they are!" Then they broke the dam that held the water in the pond, and the water flew in a river that carried away all the white men and a few of the black men too. But before they were carried away, the whites stole something that belonged to us... like all this knowledge that you get at school. You didn't behave properly... you just got up and stole this thing and left.

Up to this point, Jacop's narrative mirrors many other past and current myths found throughout PNG (e.g., Bashkow 2006, Burridge 1995, Busse 2005, Jorgensen 2001, Kirsch 2006, P. Lawrence 1989, Worsley 1968). As in the origin myths collected by Blackwood, all humans were created together in one place from a single human body. Out of all the people of the world, however, the Anga were the first to emerge from the pool; something that, in a culture where primogeniture is (at least ideologically) important for accessing land and secret knowledge, is indicative of a certain degree of superiority. In contrast to whites, moreover, they were fully clothed, and thus recognisably human and "pleasing" to the culture heroes. However, in this modern rendition the cunning whites manage to trick them and misappropriate the power to obtain the cargo now associated with them, which, in accordance with the symbolism of the old myths, my informants associated with fire and light and thus, by extension, with the broader capacity to be fully knowledgeable and efficacious humans. Thus, if on the one hand Jacop's story maintained a longstanding Anga claim to "cosmologically-ordained exceptionalism and entitlement" (Wardlow 2008: 6), it also claimed that whites had effectively subverted their intended centrality in the cosmic order.

Current Anga myths also incorporate the old tale about a river that springs forth to carry some of the ancestors off to the sea. This time, however, it is the whites and not some generic ancestors who are taken away. What is more, as can be seen from the following extract from a different interview, ${ }^{9}$ in many modern myths this departure from the land of creation is framed, not in terms of an accidental happening, as appeared to have been the case earlier, but as divine retribution for their primordial act of treachery.

It was cold and wet inside the tree, so Akheānqa [the culture hero] and his wife made a fire to warm the people who had emerged from it. He then made ornaments and clothes and gave them to the Kukukuku. To the others, he only gave leaves to cover themselves up. They had a singsing [Tok Pisin: 'ceremonial dance'] then Akheānqa sent the non-Kukukuku away to their respective lands, leaving Niyantona [Hamtain: loosely translatable as 'the metamorphosis', this name is often used to indicate the place where humans emerged from the pool/tree] to the Kukukuku. But the white man saw Akheānqa's fire, which he kept hidden under his bark cloak. The white man stole this light, and Akheānqa became very angry and shot an arrow at the 
aitapa [Hamtai: 'a type of pool that forms inside large hollow tree trunks', which this version of the origin myth identified as the pool of creation]. The pool was hit and exploded, and the first river shot forth and carried all the wiya people [Hamtai: 'non-Kukukuku'] away, including the white men, who were still holding onto Akheānqa's light.

According to my informants, this original immoral act and the consequent banishment of a part of humanity from the land of creation resulted in a situation whereby whites possess all knowledge and modern cargo but are disconnected from the land, whereas the Kukukuku remain firmly anchored to the land but lack the knowledge and material tools needed to exploit it. To the small mining community where I lived, this parable of primordial theft echoed both the colonial "plunder" of their resources and a present reality when they have gained some of those rights to gold-bearing land that they were denied in colonial times, but still lack the capital and machinery necessary for its full exploitation.

Indeed, the connection between the original theft, colonialism and the failed development of Angaland is drawn even more strongly in other indigenous narratives. For example, I was often told that the first whites had come to PNG specifically to look for the Anga, whom they knew to be the people who guarded the land of creation, a place so full of riches that it could be described as, or indeed was, the Biblical Garden of Eden. On their return, however, the whites did not hand back what they had stolen, as they ought to have done, but instead used the ancestral fire to once again appropriate what belonged to the Anga. First they used its light to locate and secure Morobe's gold and then employed its power to kidnap those Anga ancestors who were the first discoverers and rightful owners of the land and riches of Wau and Bulolo (see also Hirsch and Moretti 2010).

In light of these stories it would be legitimate to imagine that the Anga hold whites fully responsible, not only for the injustices of the colonial encounter, but also for the difficulties and inequalities of the post-independence present. Following this particular vision of culpability, many informants argued that all Anga should unite in a common struggle to secure both the restitution of the land and gold that whites "stole" from them in the colonial era, and the power they took away from them at the time of creation.

A typical example was the Kaindi Nani (Hamtai: 'older sister') Group Association. Founded in 1996 by a middle-aged Hamtai couple, the organisation comprised nearly 200 members by the mid-2000s, most of whom were Hamtai women engaged in cash cropping, marketing and artisanal mining. The group's immediate goal was to empower their members and encourage them to contribute to household resources and the local economy by engaging in various small business activities. To this end, the association 
ran the main Kaindi market, whose vendors were predominantly female, and extracted a small tax from market sellers as well as joining and membership fees, which I was told were used to maintain the market area and offer small business loans to its members. But when I interviewed Daina, the Association's founder and President, and her husband, who is the group's co-founder and Vice-Secretary, I learnt that a more covert goal also lay behind its formation. Indeed, the couple asserted that they had started the association to unite all Anga people under its umbrella, to gain recognition from the Morobe Provincial Government and the National Government, and to muster sufficient resources to sue for compensation from the Australian Commonwealth and the international mining companies that had operated in the Morobe Goldfields under colonial rule.

A second example was the Israel Niuborn Lutheran Sios Hamtai Niugini Papua. This movement, which at the time of fieldwork had already come to an end, was initiated and led by Adam, a Hamtai man from Aseki who had worked in plantations, trade stores and mines all over PNG and who had served for many years as the treasurer of the Kaindi Lutheran Church. After receiving a prophetic dream, Adam preached that the Bible was written to mask the truth that all the whites' knowledge and cargo had come from Niyantona, where God created the first people from mud and infused them with His Spirit, and that the whites had stolen these things from the Anga, for whom they were originally intended. According to Adam, the Bible was not a true account but a tok piksa [Tok Pisin: 'image or metaphor'] of deeper truths. An example that he often used to illustrate this point was that of baby Jesus resting in the manger. According to Adam, this tale was not an account of the birth of the Son of God but a secret reference to the Gift that God had intended for the Anga and that the whites had stolen and hidden away "like a baby in a manger".

From what I gathered from a number of interviews, Adam preached that the theft had greatly angered God and that this was the cause of all the conflicts, poverty, inequalities and corruption that blight the contemporary world. Only if whites returned what they stole would this pandemic of moral, material and political decay come to a close. As they refused to do so, however, the world would soon experience seven years of famine, after which the now divided three gods-i.e., God who is Spirit [Hamtai: mtnge], Jesus who is blood [Hamtai: hinge ' $\bar{a}$ ] and the Holy Spirit who is water [Hamtai: $\left.e^{\prime} \bar{a}\right]$ — would reunite in the Bulolo District. Thereafter, Adam would be reborn as the King of the Kukukuku, and Wau and Bulolo would rise again as "the New Jerusalem". What new order was to follow this deliverance remained unclear. Adam repeatedly told me that the New Jerusalem of the Kukukuku would bring justice and development to all the people of the world, including 
whites. Yet many of his followers and ex-followers hinted at this future as one in which the white men would lose all their power and would become the servants of a united Anga nation.

Straightforward as all these expressions of Anga "proto-nationalism" (Worsley 1968) and "anti-white sentiment" may appear to be, one must avoid simplistic readings of either their underlying causes or trajectory. At least as far as PNG is concerned it is essential to note that what may at first appear as indigenous "anti-colonial" discourses or movements constitute, perhaps now more than ever, single threads within much wider webs of practices and discourses of discontent, redress and renewal. To make clear what I mean by this let us return to my encounter with Jacop. Having revealed how humanity was created and how the whites had stolen the gift of knowledge from his ancestors, the miner continued his story thus:

So later my ancestors went looking for this knowledge all the way to Lae and you too wanted to come back to return this thing you took from us, so you came to Morobe and we met in Lae. Your ancestors, the first to return to PNG, to Wau-Bulolo, they came just to find us. They weren't looking for gold; they were looking for us! You see, you whites and we Kukukuku come from this same pool. Our story says that you whites and us, not all the other PNG people, but you and us, are brothers. We came out together, as brothers, you were given your languages and we ours, then that man and that woman... no, not the man, the woman! She broke the dam and you were carried away. You left us and travelled far away, and the man and woman cried because before the water was full of people and they were happy, and then all these people were taken away. And we, we were sorry too when we saw you go and we sat down and cried for our lost brothers. We cried and we asked ourselves, "Where did our brothers go?" We cried in the dark, because at the time there was no light... both the sun and the moon were not out yet. Only the man and the woman could see in that dark: it was a power that God had given them.

But your ancestors had told you that you had brothers in a faraway land, so the day came when you came looking for us and we came looking for you, and then we met in Lae. Then someone... I don't know who, I don't know the history of these first white men... of where they came from and how they got here. Were they from Germany or Australia? I am not sure, but they took their ship and came to Lae, then they used a plane to fly above the land to search for us. When they saw us they made a map and returned to Lae. They had the map now, so they left their ship and walked up to see us. When you left the coast you heard sounds in the bush... this sound is something from before, it was like the sound people made [at initiations] when they swung those things [bullroarers], but this one wasn't made by men: it just came from the bush. Before it was all over these mountains, people could hear it in the night from many directions! It was only when national independence came that this sound finally died out. 
You heard this sound, and it came from the hills. You followed it up, along the Markham River. When your ancestors had told you about your brothers you asked them: "but we don't know where they are! How can we ever meet them again?" But your ancestors just said: "that's your bush, just go there and you shall find them". So you trusted the sound and you followed it all the way to Bulolo. You met my ancestors there then came to Wau. Some of my ancestors were already there. The white men came and started mining gold, but my ancestors got up and took their bows and killed two white men, and the other white men followed the river back down to Lae. Later another white man came up here, and they killed him too. Then more whites came. They didn't come to get gold; they came to meet us, to see us in Wau and Bulolo. They already knew about us, but they were not scared. They knew there was gold there, and they wanted to get it all. They had guns, but when we attacked they could not see us and shot their guns about blindly, all over the mountains. We fought against them and almost killed them all, because our powers were strong. We shot one of them and this man used his rifle like a shield. The arrow hit his rifle and got stuck in its butt, and now that gun's in Melbourne for everyone to see. My ancestors and your ancestors had come to meet each other as brothers. You came looking for us, and we had always known you would return to us one day. But you thought that we would have white skins like you, because we were your brothers, and when you saw that we were black you didn't recognise us. So you fought against us and we fought against you, and you never gave back to us what you had taken in the beginning.

In the second part of his narrative Jacop states that whites had not come to Morobe to prospect for gold but to meet his ancestors and revisit the land of creation. He also hints that, in the end, they succumbed to the lure of gold to fight against their true siblings, who were the legitimate owners of Morobe's wealth. Unlike other informants though, he also suggests that whites had returned to New Guinea with the best intentions; i.e., to reunite with the Anga as brothers and return the knowledge and cargo they had taken away at creation. If this did not actually eventuate, it was not solely due to the greed of the white men, but primarily because of a tragic misunderstanding.

Angaland was also "the white men's bush", to which they had a right, and its guardian spirits guided them towards their long lost siblings. In turn, the Anga had been deeply saddened by the white men's departure from Niyantona and, knowing that they would eventually return, had slowly moved towards the coast in order to meet them. Nevertheless, when the two peoples finally met the whites failed to recognise their siblings because of their different skin colour, and this precipitated a war between the two parties. Unlike previous accounts, this narrative implies that, while whites had acted wrongly, they had not done so in utter bad faith. In turn, this partly converts the former 
colonisers from inherently immoral beings with whom positive relationships are not only undesirable, but perhaps also impossible, to agents with whom coexistence, co-operation and even brotherly unity could, and indeed should, be established if the right conditions are ever met.

Similarly less negative evaluations of past white-Anga relations were also present in many other tales I heard in the field. For instance, while still maintaining that whites have a moral responsibility to share their knowledge and resources with their Anga brothers, some informants asserted that these things were never stolen but had been given in trust to the white men by the culture hero(es) so that they could build the ships and planes they needed to reach the distant lands they had been assigned to inhabit and to one day return to Niyantona.

In addition, Jacop's last statements raise another key issue. When he affirmed that the Anga and whites are true brothers, he was quick to add that this special relationship does not also exist between the Anga and other Papua New Guineans, or between these and whites. The motive for this exclusion - and indeed one of the reasons why many of my informants shared their origin myth with me in the first place - was clearly stated by Jacop, who went on to say:

That is our story. I wanted to tell it to make you understand that this land belongs to us. It does not belong to other people... not to the Biangai, the Markham, the Salamaua, the Biaru or anyone else! This land... Wau and Bulolo and all the way down to Lae belongs to the Kukukuku! Lae is the place where my ancestors and your ancestors met, that is the boundary of our land, from there all the way to Kerema [in Gulf Province] on the other side.

As related in the first part of this paper, the Bulolo District and the Morobe Provincial Land Courts assigned customary ownership of Wau and Kaindi, where many of my informants had lived and worked for several decades, to the Biangai. On many occasions I heard angry recriminations for how the latter had benefited from schooling or aid posts much earlier than the people of the Upper Watut and the Anga interior, and how they had "stolen" all mining and logging compensation from them both before and after Independence. Similarly, I frequently encountered resentment for how the colonisers had taken thousands of indentured labourers from other parts of PNG and "dumped them" on "their" land, and also because the PNG government had systematically failed to send these "squatters" back to their villages. In fact, so strong was this anti-settler sentiment that these "outsiders", many of whom are actually second or third generation settlers, were systematically blamed for the law and order breakdown and most socio-economic problems in the Bulolo District (Jackson 2003, Sinclair 1998). 
In this light, Jacop's last statement works to assert the distinctiveness of the Anga vis-à-vis fellow Papua New Guineans and to validate their exclusive claims of ownership over those lands and resources misappropriated in the past. Further, it suggests that local demands for compensation from the former colonial masters are not just the result of the enduring social impacts of the colonial era, but also of the inability of the post-independence state to stem the flow of immigration, maintain law and order, and compensate the Anga for what they regard as their stolen properties.

With this in mind, it is possible to grasp why apparently straightforward "anti-colonial" local demands for compensation and restitution can, and indeed often do, turn in mid air into what may appear to be puzzling and contradictory calls that the white men return to administer PNG. Indeed, Jacop's own narrative followed that trajectory, and he later continued thus:

Now let me tell you this as well, all of you white men already have your own governments, but nobody trusts us Kukukuku. When you return to your school, I want you to tell everybody that I want to change our law. I don't like the new law; I prefer the law of the time of the white man. When the Australians came here and brought their own law it was a good time. So I want them to take their law and our own law and mix them together, and I want the Queen to give us our own government because when we got independence all the other people of PNG took over the government and forgot about us. The Sepik and the islanders took over the government and made everything worse. But we Kukukuku are the biggest language [ethnic group] in PNG, our land is the largest in the country, so we must have our own government. I don't like this Papua New Guinea Government, we must get our own government and survey our boundaries and send all the other people [who have settled in our land] back to their own places: the Papuans to Papua, the Highlanders to the Highlands, the Sepiks to the Sepik, they must all go away! We will get all the land from Kerema to Lae. We will look after the other language groups who live there, but the land will be ours.

If the white man comes and gives us this government, we will become true brothers again, then they can come back to Wau and Bulolo and work with us. We want the white men to come back, because when we send our children to school and they get into government they forget about their parents back in the bush! They only think about money and they don't bring us development, and we still live in bad houses like these and we eat around with the dogs and pigs! Look at this place, we still eat with the dogs and pigs and we already have independence! We have independence but they don't know how to develop our country, so you must come back and develop it for us. You must give us our own government, because if we had our own government it would be a good one, with no corruption, our politicians would not steal our money.... 
You must come back and give us our government, then we will be true brothers. The Bible says: "if you plant corn in barren ground nothing will come of it, but if you plant in good land there will be food for all men", and it also talks about the Garden of Eden! Now, where do you think this Garden of Eden is, in the white man's land? No! God himself says: "if you believe in Me, you will eat of this food; if you believe in me, you will live in the Garden of Eden." Ok, now the Government gives all its money to other provinces, all the other provinces control the Government, but the Government has no food. If you come back and give us our own government, if you come and mine with us and the white men from before give us back the gold they took away and you open schools and develop us, this place will become the Garden of Eden... this place IS the Garden of Eden!

You must do these things for us, and we will be brothers again. We like you, but you wasted time and you didn't help us! Why did you waste so much time? You know us; you know we are brothers, why didn't you help us? We've already had thirty years of independence, and yet we have nothing! We are still living like this. God has put these words in the Bible, about corn and the Garden of Eden, to show us the way; now it's time for you white men and us Kukukuku to follow them up!

In the final part of his speech, Jacop accuses the PNG state of having favoured other people over his. As he condemns post-independence "law" and praises that which existed under colonial rule, so too did other miners I interviewed criticise current political, social and economic realities by contrasting them with an idealised colonial situation. In many cases, this discontent with the postcolonial situation took the form of direct criticisms of Michael Somare - the first Prime Minister of Papua New Guinea who was once again holding that office at the time of my fieldwork-for having "chased the whites out" of the country to appropriate all state resources for himself and his (Sepik) people (see Mimica 1981).

Like many peoples in PNG and beyond (Bashkow 2006, Bissell 2005, Brosius 2006, Ferguson 2002, Halvaksz 2008, Kirsch 2006, Knauft 2002, Robbins 1998, Wardlow 2005, 2008), Anga feel that the post-independence state failed to represent and "develop" them properly and thus aspire to form their own government, either as a province within a federal PNG or as a wholly independent country. Returning to our two previous examples, one of the most crucial tenets of the Israel Niuborn Luteran Sios Hamtai Nugini Papua was that the national government was stealing Anga resources and refusing to give them a fair share of development and an independent government for fear that they would become too strong and take over the country. Similarly, the Nani Association was seeking not only to claim monetary compensation 
from the former colonial power and the old mining companies, but also to campaign to form an independent pan-Anga province that would administer these resources to the exclusive benefit of all Anga.

It is precisely in the context of this perceived post-independence decline, disillusionment and secessionist desires that, as is again increasingly reported in Melanesia and beyond (see Bashkow 2006, Brosius 2006, Ferguson 2002, Robbins 1998, 2004), new strategies of redress of colonial harm come to be articulated. Here, the former colonial masters, who are seen as wielding enough power to bring about the formation of an independent Anga polity and sufficient knowledge and capital to ensure its viability, reappear as potential allies. Hence Jacop's desire that the Queen should give independence to the Kukukuku and that the whites should return to mine their land. Nevertheless, all informants insisted with Jacop that the Australians should return, not as masters, but as respectful and nurturing guardians and that they should not impose "their law", as they had done in colonial times, but should reconcile it with the traditional ways of the Anga to foster local development and make the Anga their equals, thus re-establishing the original unity between Anga and whites postulated in myth. Then, and only then, will they be forgiven for the evils they are seen to have committed both in the mythical time of creation and in the colonial past.

Apart from their role of allies and protectors against other PNG ethnolinguistic groups and the State, Jacop hints to a further reason why the return of the whites is necessary for the development of his people. Thus if on the one hand he suggests that a government of the Anga and for the Anga would eliminate corruption and guarantee fast and equitable development, on the other he does not fail to criticise what could be described as the "internal elites", asserting that the few Anga who have the opportunity to acquire schooling, knowledge and political power always employ it for their personal gain, leaving the rest of their people to suffer in "sub-human" conditions of poverty and squalor or, as he puts it, to "eat around with the dogs and pigs".

Similar forms of self-criticism were put forward whenever my informants discussed why their people "had failed to achieve development" as fast as other ethno-linguistic groups of PNG. Very often these explanations pointed to the greed and corruption of particular sections of the Anga community. For instance, Daina and her husband told me that they had decided to form a women's association to achieve Anga unity and self-government because all other associations (such as the miners or landowners associations) in the Bulolo District and wider Angaland were dominated by men, and men did not care about their women, their children and each other, but only about getting money to spend for themselves. Similarly, those Upper Watut landowners who were due to receive compensation from MCG were frequently berated for their unwillingness to share these windfalls with their fellow Anga. 
Such targeted accusations were nevertheless just one part of a more general critique of Anga society, culture and morality. For example, this is what a Hamtai miner called Aisaia said in a spontaneous discussion with a group of his friends and relatives: $:^{10}$

Look at the people from the Highlands, or the Manus, or the people of the coast. When one of them has a problem they all come together to help before it gets out of hand. But with us it is not like that, it's every man by himself! It's like building a house! This is a tok piksa [Tok Pisin: 'symbol, metaphor') I'm using now, to explain how it is. When a man wants to build a new house: if he's from these other places, all his people will come to help him. But when a Kukukuku starts to build a house, no one, and I really mean NO-ONE, will offer him help. He'll walk to the bush to cut timber, he'll gather leaves for the roof and the walls, he'll buy the nails with his own money, he'll work hard to build the house, and as he is panting and sweating, plenty of people will gather around to watch him but no one will help. Then, when he's almost dead and the house is finished, all his friends and relatives will come in the night to sit by his fire and eat his grub! Ok, with development it's just the same. Look at these Nä'othi'ya [a Hamtai ancestral line]. They are telling lies and getting all the money from the company [MCG]. They alone are eating, and they're giving nothing to the other clans. But in other places it's not like that. In the Highlands, when they find oil or gold or whatever they will all benefit from it, they will all eat the money.

As is again the case among many peoples in Melanesia and beyond, we can see that the inequalities of the colonial era, coupled with the enduring if not increasing marginality and decline of the postcolonial age, fostered a discursive dynamic whereby, in certain contexts, Anga criticise their own culture and morality by contrasting it to an idealised portrayal of other PNG peoples. And it is in light of this sense of at least partial self-blame for the ills of modernity that the former colonial masters come to play yet another role in Anga discourses of colonialism: that of impartial outsiders and "moral redeemers" who may help ensure that all sections of Anga society act in unison for their "common good" (Bashkow 2006, Bissell 2005, Busse 2005, Jacka 2007, Robbins 1998, 2004).

$$
\text { *** }
$$

As I noted in the first part of this paper, there is a widespread sentiment among the Anga communities of the Bulolo District that Australia (or other "white governments") and pre-independence developers should compensate them for the land and resources they exploited in colonial times. As others noted, this feeling of exclusion is also informing local struggles to secure substantial infrastructure, services and economic benefits from present-day 
resource developers (Burton 2001, Jackson 2003). While rooted in a series of historical events, this desire for restitution cannot be understood solely in terms of a straightforward Western sense of history - that is by reference to "objective" historical episodes that occurred in a particular epoch known as "the colonial era". Rather, its causes and expressions are fully grasped only in relation to a wider mythopoetic rendering of Anga/non-Anga relationships which encapsulates not only the colonial encounter but also that taim bipo [Tok Pisin: 'time before'] stretching all the way back to the creation of humanity and the cosmos, and which reflects present preoccupations and aspirations as much as it does the unfolding of past occurrences.

In this sense, this account of Hamtai-Anga creation myths constitutes first and foremost what Jorgensen (2001) defined as an attempt to "historicise culture and culturalise history" or, as Biersack (1991) put it, to track the complex process of structuration between global and local and between history and culture. Through a historically informed comparison of my material with that collected by Blackwood in the 1930s, I aimed to show how certain themes, symbols and cultural logics of the old mythical narratives have been creatively transformed in present-day renditions to reflect, give meaning to and seek ways to obviate the history of the Morobe Goldfields and the broader Anga colonial experience. Thus I reported how the list of peoples that emerged from the primordial pool has extended to include whites. I explained that the old story of ancestors carried to the coast by a bursting river now describes the whites' departure from the land of creation. I argued that the symbolic force of fire, now said to have been stolen by whites shortly after creation, at once explains this initial separation, motivates the whites' return in colonial times and explicates how they were able to expropriate the Anga of their land and wealth. As such, I suggested that this established trope is now employed both to make sense of past and enduring differences in wealth, power and knowledge between the Anga and the colonisers, and to reassert the humanity and equality - if not the superiority — of the Anga people. In turn this shows that, just as history must be kept in mind when analysing present day Anga culture, discourse and aspirations, so it must be remembered that, in the Morobe Goldfields as in many other parts of the Pacific, myth constitutes what Kirsch (2006) called a form of "indigenous historical analysis" by which local actors seek both to give meaning to and transform their past, present and future exchange relationships with one another, other indigenous groups and whites.

If viewed through the lens of contemporary myth, Anga demands for the restitution of gold and compensation from former colonisers and resource developers are far from simple calls for monetary reparation for quantifiable items of misappropriated wealth. Rather, the gold that whites are charged with having stolen and are demanded to return is, like the ancestral fire they took at 
creation, a condensed symbol of something wider, including the desire to obtain political independence and self-determination and gain social and economic equality with the former colonial masters and "whites" more generally (Burridge 1995, P. Lawrence 1989, Lindstrom 1993, Worsley 1968).

Far from merely reflecting and "making sense" of the past, myth articulates alternative visions of how things could and should have occurred in the past, could and should unfold in the present, and ought to be made in the future. Of course, as suggested by Biersack (1991), this mythopoetic process of reconstructing history and imagining futures is an inherently political exercise where the symbolic polyvalence of myth plays a very important role. Thus, in past and current Anga creation myths, people come at once potentially divided and united. From the beginning of time to the present, the history of humanity is one of progressive differentiation from an original state of unity. This process of fractal multiplication (Wagner 1978: 110), which is depicted alternatively as a value-neutral and casual accident, the consequence of innate and morally salient differences between the created, and/or as retribution for conscious immoral acts committed by one group at the expense of others depending on the political objectives of each particular narrator at the time of each particular performance, remains in essence a series of fluid, contingent and reversible images.

As a result, the Hamtai origin myth is now deployed to condemn past and present inequalities between Anga and whites, blame these on the immoral nature and sinful actions of whites and their ancestors, foster an image of unity between Anga communities, and imagine a tomorrow where these power relations will be reversed. At the same time, however, that same myth is also used to invoke a future in which the former colonial masters will reunite with their Anga brothers, return to them the knowledge, power, dignity and humanity they took away from them, and stand as their moral equals, allies and protectors against the greed of other PNG people and of their own internal elites.

As is the case for myth more generally, therefore, Anga narratives about the colonial encounter and its roots in the events of creation embody at once the language of potential identity, unity and communal action, and that of competition, argument and political division (Leach 1954), thus revealing the full complexity of indigenous understandings of the past, opinions of the present and orientations to the future.

In recent decades historians and anthropologists have critiqued past models where "the colonised" were represented as a homogeneous front united in a struggle of "resistance" against a similarly monolithic "coloniser". This paradigm shift arose in part from the growth of postmodernist thinking in the two disciplines. Yet it also reflected changed historical circumstances in 
which the demise of colonialism highlighted political differences between and within indigenous communities which, while always present, were perhaps previously more obfuscated by the veil of metropolitan oppression and power. In any event, the shift led to the recognition that the old oppositional models denied the socio-political agency and cultural creativity of the colonised, whose actions were cast as simply reactive to the agency of the centre, and thus dangerously simplified reality by "sanitising" the internal politics of the oppressed (Biersack 1991, Thomas 1997).

In this sense, my material suggests that taking myth seriously as a form of "indigenous historical analysis" (Kirsch 2006) can reveal the interplay of culture and history in the articulation of local visions of moral renewal and social and political strategies for change and for redress (Jorgensen 2001, Kirsch 2006). In turn, this can help us move beyond a unidirectional, topdown view of local action as mere reaction to a history imposed from the centre. Further, it alerts us to the complexity of indigenous attitudes towards the former colonial masters, which include not only a desire for revenge or the truncation of all relations with whites (though this undoubtedly exists at certain times and in specific contexts) but also the hope that equal and positive relations with them may one day be achieved. At the same time, the material presented here highlights the fact that local communities are as disaffected with their national elites and institutions, and as suspicious of other ethno-linguistic groups within the independent nation state, as they are of the former colonial administration and whites more generally. Further, it suggests that they are fully capable of self criticism when interpreting the past and articulating visions for the future. Yet such self criticism is part of a highly complex web of relational discourses and in no way signifies that the Anga cast themselves exclusively in the role of passive subjects subordinate to more powerful external agents who, although portrayed at times as somewhat idealised allies, are nevertheless also objects of critique and reproach in other contexts (Bashkow 2006; see also Knauft 2002; Robbins 2002, 2004).

In turn, this confirms that, while history and anthropology should continue their role of advocacy of the opinions and rights of those at the wrong end of unequal power relations, this moral agenda is best served by moving beyond the rigidly homogenising and dichotomising oppositional models of past historiography and anthropological theory in favour of what Thomas (1997: 227) called a representational and analytical shift "from contrast to relation(s)". In this way, our attempts to understand contemporary Pacific discourses about colonialism, restitution and redress will highlight the many real injustices of yesteryears, the discontents of today's colonial, postcolonial and neocolonial regimes, and the hopes people harbour for 
the future, but without denying the creativity, critical agency and human capacity for both unity and divisiveness that mark their origin, pace and complex trajectories.

\section{NOTES}

1. The term Anga indicates a linguistic family of 13 related languages whose speakers live across the Gulf, Eastern Highlands and Morobe provinces of PNG. In the colonial literature these people were known as "Kukukuku" in Papua and "Rock-Papua" or "Rockmenschen" ('Skirt Papuan' or 'Skirted men') in German New Guinea (Detzner 1935, Wagner and Reiner 1986).

2. The label indentured labourers refers to Papua New Guineans hired under administration law with contracts of two to three years, which could be renewed after a break of a few months (Healy 1967, Howard 1991, Kuluah 1983, Nelson 1976).

3. To give a clearer sense of this contribution, it is sufficient to note that in the ten years before the Second World War Bulolo Gold Dredging alone provided 18.14 percent of all government revenues of the Mandated Territory of New Guinea, while royalties from gold-mining accounted for a total of 25.7 percent of them (Healy 1972: 500).

4. In contrast with this, my Hamtai informants denied that Biangai even existed as a local group before the colonial encounter, claiming instead that they were a recent amalgamation of Biaru and Kaiva groups from outside the Wau-Bulolo District. This was undoubtedly said in order to counter Biangai claims as longstanding local landowners in the Morobe Goldfields.

5. The kina (PGK) is the national currency of Papua New Guinea. Its average value in 2005 was 0.33008 USD (see http://www.bankpng.gov.pg and http://www. oanda.com/convert/fxhistory, both retrieved from the World Wide Web on 24 February 2006).

6. As is common in PNG, my informants routinely used the Tok Pisin terms ol waitman and ol waitman na meri ('white men' and 'white men and women/white people'), or the Hamtai words hamāto and hamāti (literally 'red man' and 'red woman') (Godelier 1986: 206, note 2) to refer to their former colonisers and to people from Europe, America, Australia, New Zealand and Asia (Bashkow 2006: 6). As such, the terms "whites" and "white men" as used in the remainder of this paper reflect local usage and are best understood as labels for the former colonisers of PNG and, more broadly, for people associated with countries (in the West and beyond) which my informants regarded as comparatively wealthier.

7. A pseudonym, like all informant names herein

8. Jacop's story was related in Tok Pisin intermixed with Hamtai.

9. The following narrative was related entirely in Hamtai.

10. The following dialogue occurred entirely in Tok Pisin. 


\section{REFERENCES}

Bamford, Sandra, 2007. Biology Unmoored: Melanesian Reflections on Life and Biotechnology. Berkeley: University of California Press.

Bashkow, Ira, 2006. The Meaning of Whitemen: Race and Modernity in the Orokaiva Cultural World. Chicago: University of Chicago Press.

Biersack, Aletta, 1991. Introduction: History and theory in anthropology. In A. Biersack (ed.), Clio in Oceania: Toward a Historical Anthropology. Washington: Smithsonian Institution Press, pp. 1-36.

Bissell, William Cunningham, 2005. Engaging colonial nostalgia. Cultural Anthropology, 20 (2): 215-48.

Blackwood, Beatrice, 1939. Life on the Upper Watut, New Guinea. The Geographical Journal, XCIV (1): 11-28.

1978. The Kukukuku of the Upper Watut. Oxford: Pitt Rivers Museum.

Bonnemère, Pascale, 1996. Le pandanus rouge: Corps, différence des sexes et parenté chez les Ankave-Anga (Papuasie-Nouvelle-Guinée). Paris: CNRS-Éditions de la Maison des Sciences de l'Homme.

Brosius, Peter, 2006. Between politics and poetics: Narratives of dispossession in Sarawak, East Malaysia. In A. Biersack and J.B. Greenberg (eds), Reimagining Political Ecology. Durham: Duke University Press, pp. 281-322.

Burridge, Kenelm, 1995. Mambu: A Melanesian Millennium. Princeton: Princeton University Press.

Burton, J., 2001. Morobe Gold and Silver Project: Socio-Economic Impact Study, Vol. I-III. Port Moresby: Morobe Goldfields Consolidated.

Busse, Mark, 2005. Wandering hero stories in the Southern Lowlands of New Guinea: Culture areas, comparison, and history. Cultural Anthropology, 20 (4): 443-73.

Detzner, Hermann, 1935. Moeurs et coutumes des Papous: Quatre ans chez les cannibales de Nouvelle-Guinee, 1914-1918. Paris: Payot.

Fabian, Johannes, 1983. Time and the Other: How Anthropology Makes its Object. New York: Columbia University Press.

Ferguson, James G., 2002. Of mimicry and membership: Africans and the "new world society". Cultural Anthropology, 17 (4): 551-69.

Godelier, Maurice, 1986. The Making of Great Men: Male Domination and Power among the New Guinea Baruya. Cambridge: Cambridge University Press.

Halvaksz, Jamon, 2006. Cannibalistic imaginaries: Mining the natural and social body in Papua New Guinea. The Contemporary Pacific, 18 (2): 335-59.

2008. Whose closure? Appearances, temporality, and mineral extraction in Papua New Guinea. Journal of the Royal Anthropological Institute, 14: 21-37.

Hanson, L.W., B.J. Allen, R.M. Bourke and T.J. McCarthy, 2001. Papua New Guinea Rural Development Handbook. Canberra: Australian National University.

Healy, A.M., 1965. Ophir to Bulolo: The history of the gold search in New Guinea. Historical Studies: Australia and New Zealand, 12 (45): 103-18.

1967. Bulolo: A History of the Development of the Bulolo Region. New Guinea Research Bulletin No.15. Canberra: Australian National University. 1972. Goldfields. In P. Ryan (ed.), Encyclopaedia of Papua New Guinea, Vol. I. Melbourne: Melbourne University Press, pp. 499-501. 
Herdt, Gilbert H., 1981. Guardians of the Flutes: Idioms of Masculinity. Chicago: University of Chicago Press.

Hirsch, Eric and Daniele Moretti, 2010. One past and many pasts: Varieties of historical holism in Melanesia and the West. In T. Otto and N. Bubandt (eds), Experiments in Holism: Theory and Practice in Contemporary Anthropology. Oxford: Wiley-Blackwell, pp. 279-98.

Howard, Michael C., 1991. Mining, Politics and Development in the Pacific. Oxford: Westview Press.

Imbun, Benedict Y., 2006. Local laborers in Papua New Guinea mining: Attracted or compelled to work? The Contemporary Pacific, 18 (2): 315-33.

Jacka, Jerry K., 2007. Whitemen, the Ipili, and the city of gold: A history of the politics of race and development in Highlands New Guinea. Ethnohistory, 54 (3): 445-72.

Jackson, Richard T., 2003. Morobe Gold Project Social Impact Assessment: Base-Line Study. Manila: Richard T. Jackson Consultancy Services.

Jorgensen, Dan, 2001. History and the genealogy of myth in Telefolmin. Paideuma, 47: 103-28.

Kirsch, Stuart, 2006. Reverse Anthropology: Indigenous Analysis of Social and Environmental Relations in New Guinea. Stanford: Stanford University Press.

Knauft, Bruce M., 2002. Exchanging the Past: A Rainforest World of Before and After. Chicago: University of Chicago Press.

Kuluah, Albert, 1983. Wokim gold long Morobe, 1922-1942. Paper presented to the Conference on Small Scale Mining in Papua New Guinea, University of Technology, Lae, 4-8 June.

Lawrence, Peter, 1989. Road Belong Cargo: A Study of the Cargo Movement in the Southern Madang District, New Guinea. Prospect Heights: Waveland Press.

Lawrence, Tjamei, 1994. Impact of mining in Papua New Guinea: The Morobe goldfield. In J. Morrison, P. Geraghty and L. Crowl (eds), Science of Pacific Island Peoples, Vol. III: Land Use and Agriculture. Suva: Institute of Pacific Studies, University of the South Pacific, pp. 63-76.

Leach, Edmund, 1954. Myth as justification for faction and social change. In S. HughJones and S. Laidlaw (eds), The Essential Edmund Leach, Vol. II: Culture and Human Nature. London: Yale University Press, pp. 18-29.

Leahy, Michael J., 1994. Explorations into Highland New Guinea, 1930-1935. Bathurst: Crawford House Press.

Lindstrom, Lamont, 1993. Cargo Cult: Strange Stories of Desire from Melanesia and Beyond. Honolulu: University of Hawai'i Press.

Lowenstein, P.L., 1982. Economic Geology of the Morobe Goldfield, Vol. I. Port Moresby: Department of Minerals and Energy.

Mimica, Jadran, 1981. Omalyce: An Ethnography of the Ikwaye View of the Cosmos. Unpublished $\mathrm{PhD}$ thesis, Australian National University.

Nelson, Hank, 1976. Black, White and Gold: Goldmining in Papua New Guinea, 1878-1930. Canberra: Australian National University Press.

2001. Isla del Oro: Seeking New Guinea gold. In I. McCalman, A. Cook and A. Reeves (eds), Gold: Forgotten Histories and Lost Objects of Australia. Cambridge: Cambridge University Press, pp. 189-206. 
NGG Holdings Limited, 1985. Wau Mine Upgrading Environmental Plan, Vol. II. Hawthorn: Natural Systems Research.

O'Faircheallaigh, Ciaran, 1989. Colonial administration, mineral revenues and economic development: New Guinea 1926-40. In S. Latufeku (ed.), Papua New Guinea: A Century of Colonial Impact, 1884-1984. Port Moresby: National Research Institute and University of Papua New Guinea, pp. 343-55.

Robbins, Joel, 1998. On reading "world news": Apocalyptic narrative, negative nationalism and transnational Christianity in a Papua New Guinea society. Social Analysis, 42 (2): 103-30.

2004. Becoming Sinners: Christianity and Moral Torment in a Papua New Guinea Society. Chicago: University of Chicago Press.

Roberts, Jan, 1996. Voices from a Lost World: Australian Women and Children in Papua New Guinea before the Japanese Invasion. Alexandria: Millennium Books.

Simpson, Colin, 1953. Adam with Arrows: Inside New Guinea. London: Angus and Robertson.

Sinclair, James P., 1966. Behind the Ranges: Patrolling in New Guinea. Cambridge: Cambridge University Press.

1985. Papua New Guinea: The First 100 Years. Bathurst: Robert Brown and Associates.

1998. Golden Gateway: Lae and the Province of Morobe. Bathurst: Crawford House Publishing.

Thomas, Nicholas, 1997. In Oceania: Visions, Artifacts, Histories. Durham: Duke University Press.

Tudor, J., 1977. PNG as one of the last havens for old-time gold-seekers. Pacific Islands Monthly, (May): 63-67.

Turner, Victor, 1967. The Forest of Symbols: Aspects of Ndembu Ritual. Ithaca: Cornell University Press.

Wagner, Herwig and Hermann Reiner (eds), 1986. The Lutheran Church in Papua New Guinea: The First Hundred Years, 1886-1986. Adelaide: Lutheran Publishing House.

Wagner, Roy, 1978. Lethal Speech: Daribi Myth as Symbolic Obviation. Ithaca: Cornell University Press.

Wardlow, Holly, 2005. Transformations of desire: Envy and resentment among the Huli of Papua New Guinea. In J. Robbins and H. Wardlow (eds), The Making of Global and Local Modernities in Melanesia: Humiliation, Transformation and the Nature of Cultural Change. Burlington: Ashgate, pp. 57-71.

2008. "They have forced us back to the ground": Narrating decline in Tari, Papua New Guinea. Paper presented at the AAA Meeting, San Francisco, November.

Worsley, Peter, 1968 [1957]. The Trumpet Shall Sound: A Study of "Cargo" Cults in Melanesia. 2nd augmented edition. New York: Schocken Books. 


\begin{abstract}
This paper compares versions of the same origin myth collected from the Anga people of the Morobe Goldfields in Papua New Guinea in the 1930s and 2000s. It aims to show that myth is a form of "indigenous historical analysis" that reveals how local communities creatively make sense of, and seek to shape, past and future relations with each other and the wider global order. It further seeks to highlight the complex ways Anga communities articulate the causes and legacies of colonisation, and how these are also informed by current local disputes and by dissatisfaction with perceived marginality and decline in the post-independence order.
\end{abstract}

Keywords: Anga, colonialism, decline, mining, myth 